\title{
Urolithiasis and hepatotoxicity are linked to the anion transporter Sat1 in mice
}

\author{
Paul A. Dawson, ${ }^{1}$ Christopher S. Russell, ${ }^{2}$ Soohyun Lee, ${ }^{1}$ Sarah C. McLeay, ${ }^{1}$ \\ Jacobus M. van Dongen, ${ }^{3}$ David M. Cowley, ${ }^{3}$ Lorne A. Clarke, ${ }^{2}$ and Daniel Markovich ${ }^{1}$
}

${ }^{1}$ School of Biomedical Sciences, University of Queensland, Brisbane, Australia. ${ }^{2}$ Department of Medical Genetics and the Child and Family Research Institute, University Of British Columbia, Vancouver, Canada. ${ }^{3}$ Pathology Department, Mater Misercordiae Hospital, South Brisbane, Australia.

\begin{abstract}
Urolithiasis, a condition in which stones are present in the urinary system, including the kidneys and bladder, is a poorly understood yet common disorder worldwide that leads to significant health care costs, morbidity, and work loss. Acetaminophen-induced liver damage is a major cause of death in patients with acute liver failure. Kidney and urinary stones and liver toxicity are disturbances linked to alterations in oxalate and sulfate homeostasis, respectively. The sulfate anion transporter-1 (Sat1; also known as Slc26a1) mediates epithelial transport of oxalate and sulfate, and its localization in the kidney, liver, and intestine suggests that it may play a role in oxalate and sulfate homeostasis. To determine the physiological roles of Sat 1 , we created Sat $1^{-/-}$mice by gene disruption. These mice exhibited hyperoxaluria with hyperoxalemia, nephrocalcinosis, and calcium oxalate stones in their renal tubules and bladder. Sat $1^{-/-}$mice also displayed hypersulfaturia, hyposulfatemia, and enhanced acetaminophen-induced liver toxicity. These data suggest that Sat1 regulates both oxalate and sulfate homeostasis and may be critical to the development of calcium oxalate urolithiasis and hepatotoxicity.
\end{abstract}

\section{Introduction}

Oxalate is a metabolic end product excreted into the urine (1), whereas sulfate $\left(\mathrm{SO}_{4}^{2-}\right)$ is highly reabsorbed by the kidneys $(2,3)$, playing important roles in many biochemical reactions. The regulation of oxalate and sulfate homeostasis is complex, with the kidney and liver playing critical roles. The sulfate anion transporter-1 (Sat1; ref. 4) is localized to the basolateral membrane of the renal proximal tubule (5) and the sinusoidal membrane of hepatocytes (6), where it mediates anion exchange $(2,7,8)$. The human SAT1 (9) and mouse Sat1 (7) genes - also known as SLC26A1 and Slc26a1, respectively - are located within exon 2 /intron 2 (on the opposite strand) of the $\alpha$-L-iduronidase (IDUA) gene (10). IDUA deficiency leads to mucopolysaccharidosis type I, a lysosomal storage disorder resulting from defective lysosomal degradation of glycosaminoglycans (11). Despite numerous studies characterizing Sat 1 transport properties and tissue localization $(2,9,12,13)$, the physiological roles of Sat 1 in vivo have not been resolved. To our knowledge, Sat 1 has not been linked to any human disorders, and its role within the IDUA gene is unknown; therefore, we generated a Sat $1^{-/-}$mouse by targeted disruption in order to characterize its functions in vivo. Sat $1^{-/-}$mice showed perturbations in oxalate and sulfate homeostasis, leading to urolithiasis and hepatotoxicity, respectively.

\section{Results}

Sat $1^{-/-}$mice. Our targeting strategy replaced Sat 1 exon 3 with a neomycin resistance $\left(\right.$ neo $\left.^{\mathrm{R}}\right)$ cassette (Figure 1A). Genomic Southern and PCR analyses confirmed deletion of Sat1 in DNA from Sat1 ${ }^{-1}$ mice (Figure 1, B-D). Genotypes of 303 mice were determined by PCR (Figure 1E): 86 were Sat ${ }^{+/+}$(approximately 28\%), 146 were Sat ${ }^{+/}$ (approximately 48\%), and 71 were Sat1 $1^{-/}$(approximately 24\%), close to the Mendelian ratio of 1:2:1. This finding indicates that loss of Sat 1 is not embryonic lethal. Because Sat1 is localized within Idua (10), our targeting strategy was designed to selectively disrupt Sat1 without

Conflict of interest: The authors have declared that no conflict of interest exists. Citation for this article: J Clin Invest. 2010;120(3):706-712. doi:10.1172/JCI31474. affecting Idua (Figure 1F). We confirmed this by determining that RT-PCR (using primers P6 and P7; Figure 1F and Supplemental Table 1; supplemental data available online with this article; doi:10.1172/ JCI31474DS1) amplified similar amounts of Idua mRNA from kidney, liver, and ileum of Sat1 $1^{-/-}$and $\mathrm{Sat1}^{+/ /+}$mice (data not shown). Idua enzyme activity in Sat1 ${ }^{-/}$liver $(0.029 \pm 0.003 \mathrm{nM} / \mathrm{min} / \mathrm{mg}$ protein; $n=3)$ and kidney $(0.015 \pm 0.001 \mathrm{nM} / \mathrm{min} / \mathrm{mg}$ protein; $n=3)$ were similar to that in $\mathrm{Sat1}_{1^{+/+}}$liver $(0.025$ to $0.050 \mathrm{nM} / \mathrm{min} / \mathrm{mg}$ protein $)$ and kidney (0.010 to $0.032 \mathrm{nM} / \mathrm{min} / \mathrm{mg}$ protein), respectively (14), which suggests that loss of Sat1 does not alter Idua function. No differences in body weight, tail length, or obvious distinguishing body features were observed in male and female $S a t 1^{-/}$mice compared with Sat $1^{+/-}$or Sat $1^{+/+}$mice ( $n=15-40$ per group) from 1 to 24 weeks of age (data not shown). Gross histological analyses of the liver and brain, where Sat 1 is normally expressed, showed no structural differences between $\mathrm{Sat1}^{-{ }^{--}}$and $\mathrm{Sat1}^{+/+}$mice (data not shown).

A single 3.8-kb Sat 1 transcript was detected in liver and kidney, but not ileum, of Sat $1^{+/+}$and $\mathrm{Sat}_{1}{ }^{+/-}$mice, but not Sat $1^{-/-}$mice (Figure 2B). Truncated cDNAs were amplified from Sat $1^{-/-}$and Sat $1^{+/-}$kidney mRNA (Figure 2C). Sequence analysis revealed Sat 1 exons skipping from 2 to 4 (Figure 2A), with this cDNA lacking the first 587 bases of the Sat 1 coding region, including the ATG start codon. Sat 1 transcripts were amplified in the distal ileum, cecum, and proximal colon (Figure 2D). Sat 1 protein was detected in basolateral membrane vesicles (BLMVs) from distal ileum, cecum, proximal colon (Figure 2E), and renal cortex (data not shown) of Sat1 $1^{+/+}$ mice, but not Sat1 ${ }^{-/}$mice. Oxalate and $\mathrm{SO}_{4}{ }^{2-}$ transport was strongly reduced in BLMVs isolated from kidney, liver, distal ileum, cecum, and proximal colon of Sat $1^{-/-}$mice compared with Sat $1^{+/+}$mice (Table 1), with no differences observed in brush border membrane vesicles (BBMVs) of Sat1 ${ }^{+/+}$and Sat1 $1^{-/-}$mice (data not shown).

Role of Sat1 in the urinary system. Sat1 $1^{-/-}$mice had infiltration of leukocytes around renal cortical vessels that was absent in $\mathrm{Sat1}^{+/+}$ mice (Figure 3, A and B). Calcium oxalate crystals were observed in the lumen of kidney cortical tubules and the bladder of Sat1 $1^{-/-}$ mice, but not Sat $1^{+/+}$mice (Figure 3, C-F). Crystals in the cortex and 
A

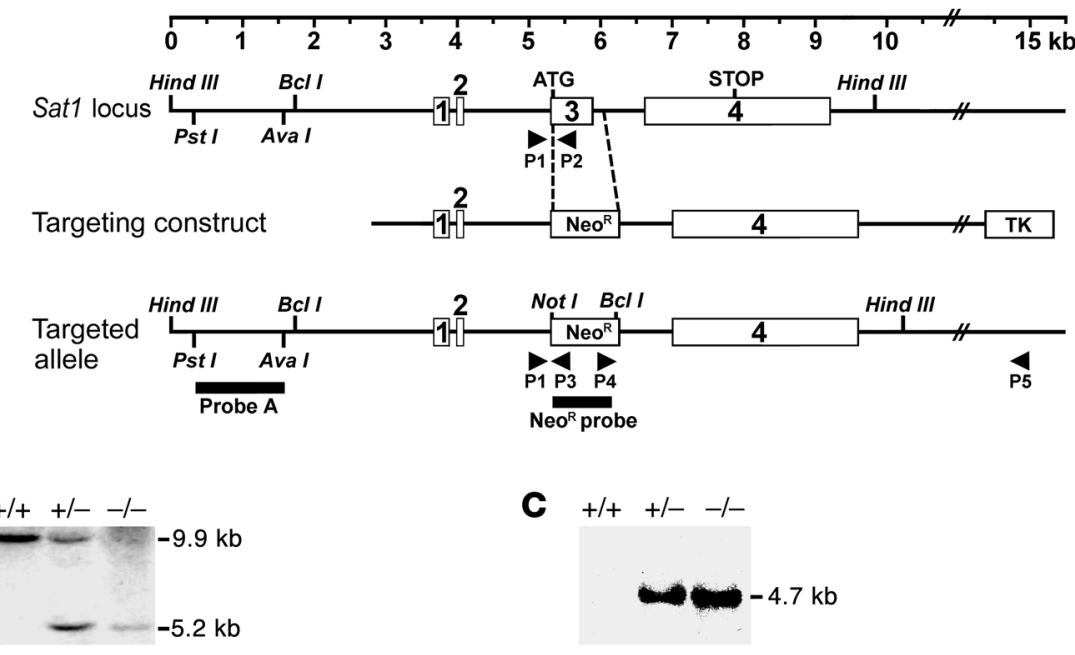

D
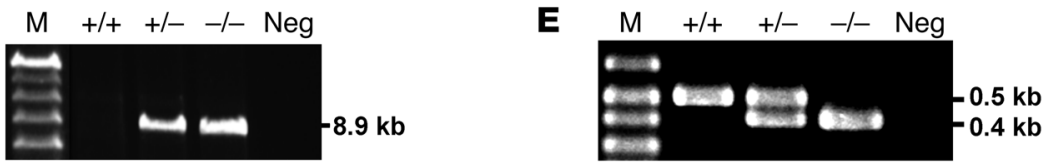

$\mathbf{F}$

Figure 1

Targeted disruption of Sat1. (A) Sat1 targeting strategy. Exons (boxes 1-4), restriction sites, probes, and primers P1-P5 are shown. Neo ${ }^{\mathrm{R}}$, neomycin resistance sequence; TK, thymidine kinase sequence. (B) Southern analysis of Hind III- and Not I-digested DNA from Sat1 ${ }^{+/+}$, Sat1+l-, and Sat1-/- mice. Probe A detected 9.9-kb wild-type and 5.2-kb targeted allele fragments. (C) Southern analysis of Bcl I-digested DNA from

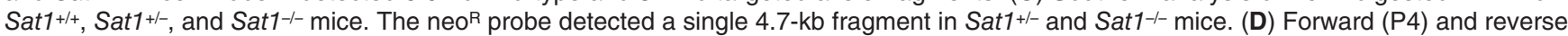
(P5) primers amplified an 8.9-kb product in DNA samples from Sat1 ${ }^{+/-}$and Sat1-/- mice. M, molecular mass ladder; Neg, negative control. (E) Primers P1 and P2 amplified a 0.5-kb wild-type fragment; P1 and P3 amplified a 0.4-kb targeted allele fragment. (F) Selective disruption of the Sat1 gene located on the opposite strand within the Idua gene. Sat1 exons (white boxes 1-4), Idua exons (black boxes 1-14), primers P6 and P7, and neomycin resistance sequence are shown.

outer medullary regions of the Sat1 $1^{-/-}$kidney (Figure 4, A and B) were mainly composed of calcium, oxygen, and carbon (Figure 4C), indicating primary composition of calcium oxalate.

Role of Sat 1 in the liver. Because sulfate is involved in detoxifying xenobiotics such as acetaminophen (APAP), and APAP administration causes rapid plasma sulfate depletion in humans and rodents $(15,16)$, we tested whether hepatic phase II sulfonation was affected in Sat $1^{-/-}$mice. As shown previously in our $\mathrm{Nas}^{-/-}$mice (17), 12-hour administration of $250 \mathrm{mg} / \mathrm{kg}$ APAP led to a 4-fold increase in serum alanine aminotransferase (ALT) in Sat1 $1^{-/-}$mice compared with $S a t 1^{+/+}$mice (Figure 5A), and extensive liver necrosis was observed in Sat $1^{-1-}$ mice, but not $\mathrm{Sat}^{+/+}$mice (Figure 5, C and D, and Supplemental Table 2). A single $250-\mathrm{mg} / \mathrm{kg}$ dose of APAP led to significantly greater reductions in glutathione (GSH) levels in Sat $1^{-/-}$mice (reduced by approximately $96 \%$ ) than in $\mathrm{Sat1}^{+/+}$mice (reduced by approxi- mately 80\%) after 2 hours; after 12 hours, basal GSH levels were restored in both $\mathrm{Sat1^{-/- }}$ and $\mathrm{Sat} 1^{+/+}$mice (Figure 5B).

Role of Sat1 in sulfate and oxalate homeostasis. Blood and urine profiling of $\mathrm{Sat1}^{-/-}$and $\mathrm{Sat1}^{+/+}$mice revealed that plasma oxalate levels increased by approximately $60 \%$, whereas serum $\mathrm{SO}_{4}{ }^{2-}$ levels were reduced by approximately $60 \%$, in Sat1 $1^{-/-}$mice compared with $\mathrm{Sat} 1^{+/+}$ mice (Table 2). Urine oxalate/creatinine and $\mathrm{SO}_{4}{ }^{2-} /$ creatinine ratios and fractional excretion index (FEI) for $\mathrm{SO}_{4}{ }^{2-}$ were significantly increased in Sat1 $1^{-/}$mice. Urinary glycolate/creatinine levels were not altered in Sat $1^{-/-}$or Sat $1^{+/+}$mice. A decrease in cecal oxalate and an increase in cecal sulfate content was observed in Sat $1^{-/-}$mice.

\section{Discussion}

Overlapping genes in eukaryotes have been thought to be rare, but more recent analyses of the human and mouse genomes (18) suggest that overlapping transcripts in mammals may be more common 

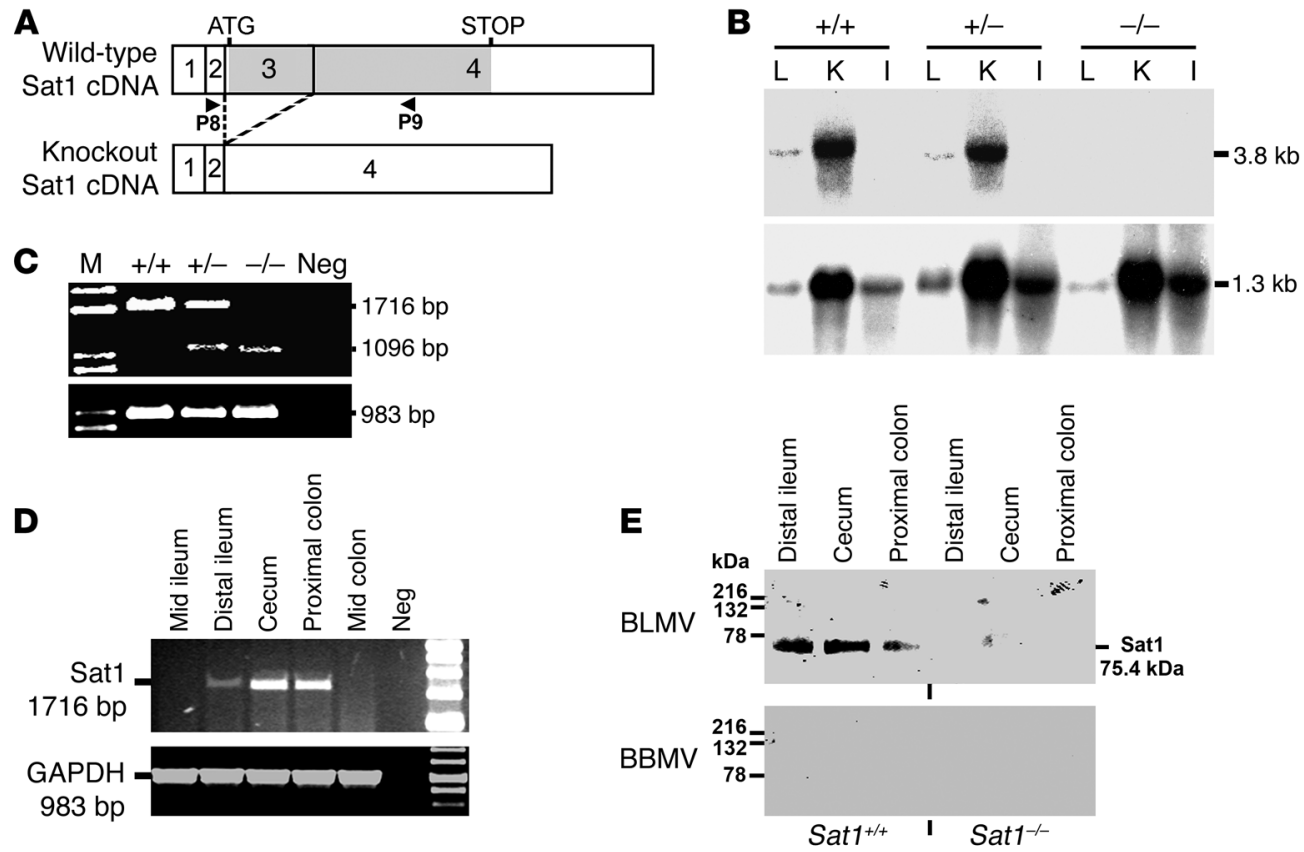

Figure 2

Analysis of Sat1 protein and mRNA. (A) Schematic of Sat1 cDNA and the predicted knockout cDNA lacking exon 3. Exons 1-4 (boxes), protein coding sequences (shading) of wild-type (3,821 nucleotides) and Sat1 knockout (3,201 nucleotides) cDNA, and primers P8 and P9 are shown. (B) Northern analysis of RNA from liver (L), kidney (K), and ileum (I) of Sat1 $1^{+/+}$, Sat1 ${ }^{+/-}$, and Sat1 ${ }^{-/}$mice. RNA was hybridized with a ${ }^{32} \mathrm{P}-\mathrm{labeled}$ Sat1 cDNA (top), showing the 3.8-kb transcript, and GAPDH cDNA (bottom). (C) Total RNA from kidney was RT-PCR amplified. A 1,716-bp wild-type product and a 1,096-bp knockout Sat1 cDNA product (top) were amplified using primers P8 and P9. A 983-bp product (bottom) was amplified using GAPDH primers. (D) Total RNA from Sat1+/+ intestinal segments was RT-PCR amplified. A 1,716-bp product was amplified using primers P8 and P9. A 983-bp product (bottom) was amplified using GAPDH primers. (E) Western analysis of protein from intestinal BLMVs and apical BBMVs. The Sat1 antibody detected a 75.4-kDa protein in Sat1+/+ BLMVs, but not in Sat1+/+ BBMVs or in Sat1/-- mice.

than previously thought. Early studies proposed that Sat1 localization within the Idua gene may produce an antisense effect between the Sat 1 and Idua transcripts and act as a potential mechanism for coordinating expression of these genes (10). Selective disruption of Idua in mice showed no change in Sat1 mRNA levels (14), and here we observed no change in the functional activity of Idua in tissues of Sat $1^{-/-}$mice, which suggests that antisense effects are unlikely to play a significant role in regulating the expression of Sat1 and Idua genes.

Urolithiasis is the most common chronic disorder of the urinary tract, with $70 \%-80 \%$ of stones being calcium oxalate crystals (19). Our observation of calcium oxalate crystals in the bladder and renal cortical and medullary tubules of Sat1 $1^{-/-}$mice suggests that Sat 1 plays a major role in renal oxalate excretion. Infiltration of leukocytes around renal cortical vessels of Sat1 $1^{-/}$mice suggests ureteral obstruction or obstructive uropathy (20). Sat $1^{-/-}$mice had significantly elevated plasma oxalate levels, a greater than 2 -fold increase in urine oxalate/creatinine ratio, no changes in urinary glycolate/creatinine levels (an indicator of hepatic oxalate production), and reduced oxalate transport in BLMVs of distal intestinal segments, which suggests that the hyperoxaluria in Sat $1^{-/-}$mice arises most likely from hyperoxalemia rather than altered renal tubular oxalate handling. No changes were observed for whole blood $\mathrm{pH}$; urine $\mathrm{pH}$; urinary protein levels; cecal water content; serum levels of creatinine, $\mathrm{Cl}^{-}, \mathrm{PO}_{4}{ }^{2-}, \mathrm{Na}^{+}, \mathrm{K}^{+}$, and $\mathrm{Ca}^{2+}$; and FEIs of $\mathrm{PO}_{4}{ }^{2-}$ and $\mathrm{Ca}^{2+}$ between $\mathrm{Sat} 1^{-/-}$and $\mathrm{Sat} 1^{+/+}$mice (Table 2), which suggests that homeostasis of these ions was not perturbed in Sat $1^{-1-}$ mice. Sat $1^{-/-}$mice had significantly decreased serum sul- fate levels, increased urine sulfate/creatinine, and increased FEI sulfate, suggesting that the hyposulfatemia in Sat $1^{-/}$mice most likely arises from increased renal excretion, as previously observed in $\mathrm{Nas}^{-/-}$mice (21). This agrees with the present observation of strongly reduced sulfate transport across renal and liver BLMVs of Sat $1^{-/-}$mice, which suggests that Sat 1 is the predominant sulfate transporter on the renal proximal tubular basolateral and liver sinusoidal membranes. The hyposulfatemia and FEI sulfate values in $\mathrm{Sat1}^{-/-}$mice were comparable to those in $\mathrm{Nas}^{-/-}$mice (21), which suggests that Sat1, together with $\mathrm{NaS} 1$, plays a crucial role

Table 1

BLMV transport of oxalate and sulfate

\begin{tabular}{lcc}
\hline & Sat1 ${ }^{+/}$ & Sat1 $^{-/}$ \\
Oxalate, pmol/mg protein/s & & \\
Kidney & & \\
Liver & $0.47 \pm 0.07$ & $0.06 \pm 0.05$ \\
Distal ileum & $1.96 \pm 0.07$ & $0.97 \pm 0.14$ \\
Cecum & $0.59 \pm 0.11$ & $0.34 \pm 0.09$ \\
Proximal colon & $1.17 \pm 0.09$ & $0.62 \pm 0.16$ \\
Sulfate, pmol/mg protein/s & $1.06 \pm 0.25$ & $0.42 \pm 0.08$ \\
Kidney & & \\
Liver & $10.72 \pm 1.28$ & $0.59 \pm 0.17$ \\
& $16.25 \pm 1.74$ & $2.57 \pm 1.16$
\end{tabular}

Results are mean \pm SEM from BLMVs pooled from 10-15 mice. 


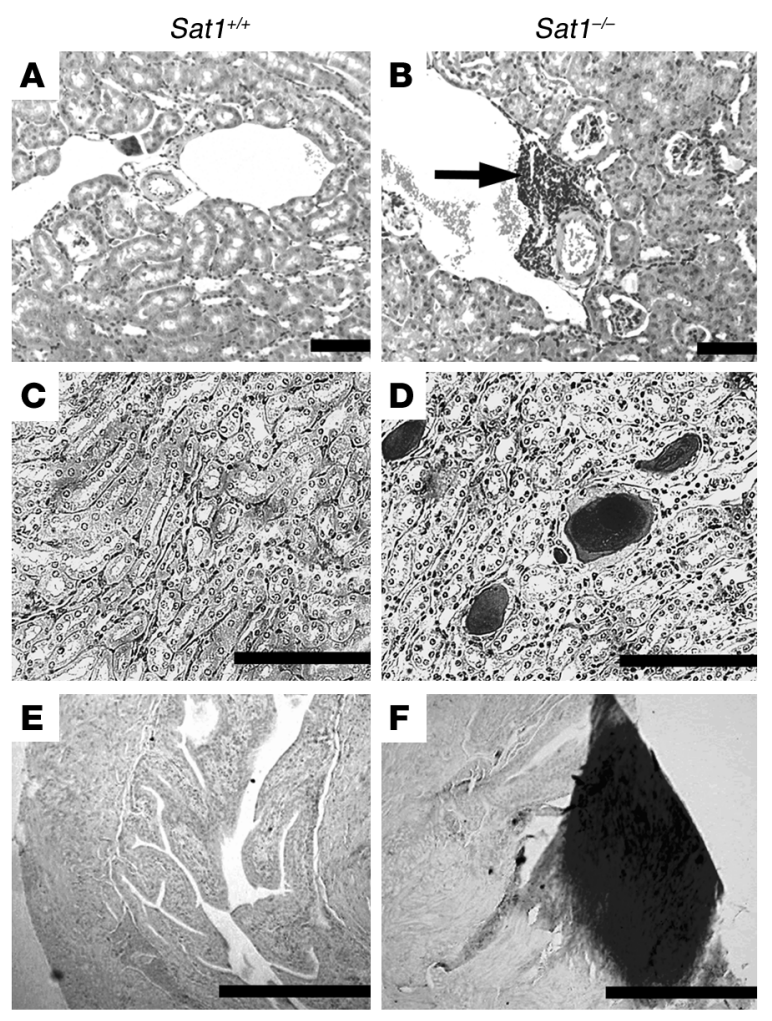

in renal sulfate reabsorption and maintenance of serum sulfate levels. Despite Sat 1 being expressed in several other tissues, including heart, brain, calvaria, and skeletal muscle (7), its role in these tissues - and to what degree these tissues contribute to circulating sulfate levels - is yet unknown. Our identification of Sat1 mRNA in the distal ileum, cecum, and proximal colon and Sat 1 protein on the basolateral membrane of these intestinal segments suggests that Sat 1 plays a role in distal intestinal oxalate and sulfate transport. This is corroborated with reduced oxalate transport in BLMVs from distal ileum, cecum, and proximal colon as well as decreased cecal oxalate content, indicating that the hyperoxalemia in Sat $1^{-/}$mice is most likely caused by reduced intestinal secretion of oxalate, as previously observed in $\operatorname{Slc} 26 a 6^{-/-}$mice $(22,23)$. Our data suggest that Sat 1 is the basolateral anion exchanger, which, together with Slc26a6 on the brush border membrane $(22,23)$, facilitates intestinal oxalate secretion.

Sulfate is required for detoxification of xenobiotics, including $\operatorname{APAP}(3)$, the leading cause of drug-related liver failure in humans $(3,24)$. Sat $1^{-/-}$mice had increased APAP-induced liver toxicity, which suggests that the hyposulfatemia in Sat $1^{-/}$mice limits the supply of sulfate for APAP metabolism, as previously demonstrated in $\mathrm{Nas}^{1^{-/-}}$mice (17). High doses of APAP cause rapid depletion of GSH, saturation of the sulfonation and glucuronidation pathways, and increased production and half-life of the toxic reactive intermediate $\mathrm{N}$-acetyl-p-benzoquinone, which leads to cellular damage and death (25). Depletion of hepatic GSH levels and the rate of cellular GSH repletion are critical factors in APAP hepatotoxicity $(26,27)$. This agrees with our observations of decreased hepatic GSH levels and increased APAP-induced hepatotoxicity in Sat $1^{-1-}$ mice. The loss of Sat 1 from the sinusoidal membranes of hepatocytes, where it facilitates sulfate import for sulfonation reactions (6), as well as the hyposulfatemia, exacerbate hepatic

\section{Figure 3}

Urolithiasis in Sat1-/- mice. (A and B) Representative H\&E-stained kidney sections showing infiltration of leukocytes (arrow) around the renal cortical vessels in $100 \%$ of Sat1-l- mice $(n=8)$, absent in Sat1 $1^{+/+}$ mice. (C-F) Representative Yasue-stained kidney (C and D) and blad$\operatorname{der}(\mathbf{E}$ and $\mathbf{F})$ sections showing calcium oxalate stones (dark staining) in kidney tubules of $47 \%$ Sat1 $1^{--}$mice $(n=15)$ and bladders of $26 \%$ Sat1-/- mice $(n=19)$, but not in any Sat $1^{+/+}$mice $(n=10)$. Gross histological analyses of additional tissues in which Sat1 is expressed (liver and brain) showed no structural differences between Sat1-/- and Sat1+/+ mice (not shown). Scale bars: $100 \mu \mathrm{m}$ (A and B); $500 \mu \mathrm{m}$ (C and $\mathbf{D}) ; 2 \mathrm{~mm}$ (E and F). sulfate depletion and drug-induced liver damage by drugs such as APAP. The roles of Sat 1 polymorphisms (28) in drug metabolism rates are currently unknown, but the present study suggests that Sat1 may play an important role.

In conclusion, this is the first study to our knowledge to demonstrate Sat 1 localization on the basolateral membrane of intestinal cells and show that loss of Sat 1 expression leads to urinary stone formation and drug-induced hepatotoxicity, owing to altered homeostasis of oxalate and sulfate, respectively. Disturbed oxalate homeostasis led to hyperoxaluria with hyperoxalemia, nephrocalcinosis, and calcium oxalate urolithiasis, whereas perturbed sulfate homeostasis led to hyposulfatemia, hypersulfaturia, and enhanced hepatotoxicity in Sat1 $1^{-/}$mice. The present study provides an animal model for characterizing the etiology and mechanisms underlying calcium oxalate urolithiasis and the hepatic phase II sulfonation pathway and represents a therapeutic target for investigating human kidney stone formation and drug-induced hepatotoxicity in the general population.

\section{Methods}

Targeting vector construction. Fragments of Sat 1 were PCR amplified and used to create the targeting vector shown in Figure 1A. A 2.3-kb fragment containing exons 1 and 2 , and an 8.0-kb fragment containing exon 4, were subcloned on either side of the phosphoglycerate kinase-neo ${ }^{\mathrm{R}}$ expression cassette of the PCAG Neo vector. Upon homologous recombination, this vector deleted approximately $0.9 \mathrm{~kb}$ of Sat 1 genomic sequences, including the ATG start codon in exon 3 (Figure 2A).

Generation and identification of Sat $1^{-1-}$ mice. The targeting construct was electroporated into 129JSv mouse ES cells. Transfectants were selected for resistance to neomycin and ganciclovir (14). Individual clones that had undergone homologous recombination were identified by Southern blot analysis using an external 1.3-kb Pst I/Ava I fragment upstream of exon 1 
A

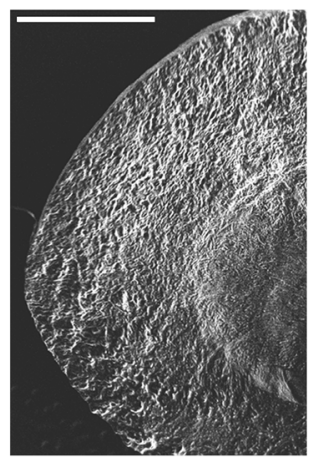

B

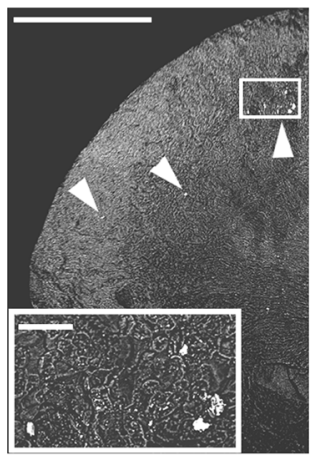

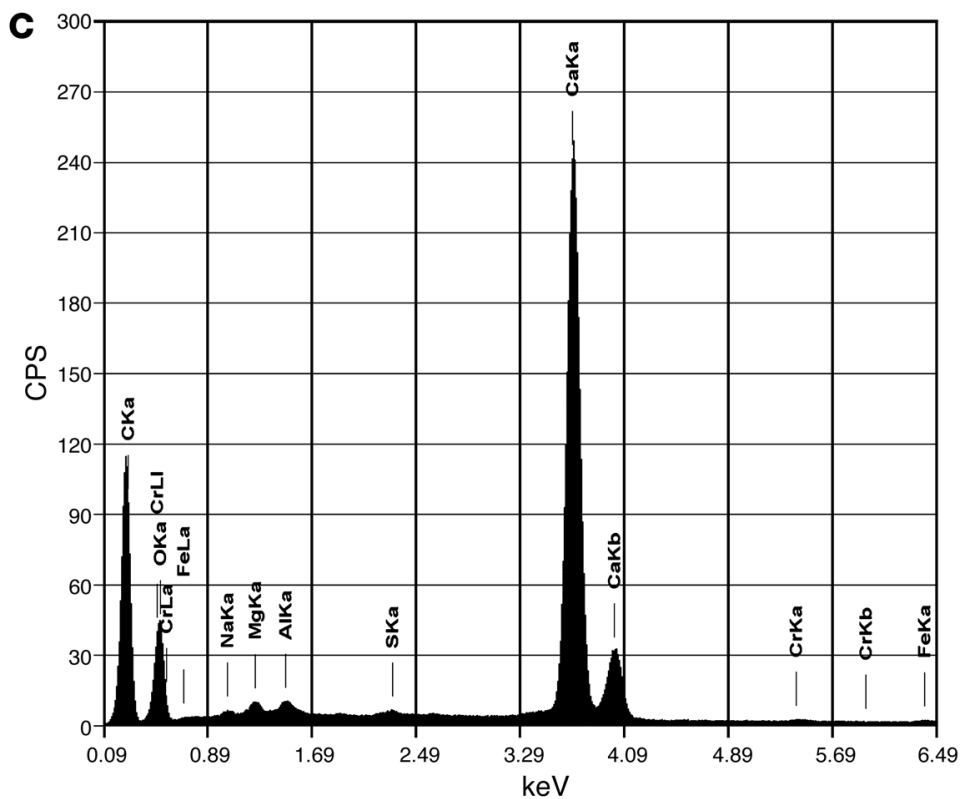

Figure 4

Energy dispersive X-ray spectrometry analysis of kidney stones in Sat1-/- mice. (A and B) Representative electron micrograph (A) and energy dispersive X-ray micrograph (B) showing kidney stones (arrowheads in B) in the renal cortex and outer medullary region of Sat1-/- mice. Highermagnification view of the boxed region in B is shown in the inset. Scale bar: $1 \mathrm{~mm} ; 100 \mu \mathrm{m}$ (inset). (C) Elemental profile of kidney stones showing abundance of calcium ( $11.01 \% \pm 0.03 \%)$, oxygen ( $36.53 \% \pm 0.22 \%)$, and carbon $(51.46 \% \pm 0.08 \%)$, as well as trace levels $(\leq 0.30 \%)$ of sodium, magnesium, aluminium, sulfur, chromium, and iron. CPS, counts per second; keV, kiloelectron volts.

as a probe (Figure 1A). Probe A detected a 9.9-kb Hind III wild-type allele fragment and a 5.2-kb Hind III/Not I recombinant allele fragment. Positive ES cell clones were injected into CD1 blastocysts that were implanted into foster mothers. Chimeric mice were bred with CD1 mice, and heterozygous offspring were intercrossed to produce Sat $1^{-/-}$mice. Tail biopsies were further analyzed by Southern blotting using a neo ${ }^{R}$ probe (Figure $1 \mathrm{~A}$ ) and by using PCR to amplify an $8.9-\mathrm{kb}$ recombinant allele fragment. PCR was performed using primer $\mathrm{P} 4$ in the neo ${ }^{\mathrm{R}}$ gene cassette and antisense primer P5 downstream of exon 4 (Supplemental Table 1 and Figure 1A). Studies were performed on male mice with a mixed genetic background (129JSv and CD1). Mice were maintained on a 12-hour light/dark cycle and fed ad libitum on standard rodent chow (diet no. AIN93G; Glen Forrest Stockfeeders). All animal experiments were approved by the University of Queensland Anatomical Biosciences Ethics Committee.

Genotyping of mice. Mice were genotyped using primer P1 in intron 2 and antisense primer $\mathrm{P} 3$ in the neo ${ }^{\mathrm{R}}$ gene cassette to PCR amplify a $0.4-\mathrm{kb}$ fragment of the recombinant Sat 1 allele (Supplemental Table 1 and Figure 1A). Primer P1 and antisense primer P2 in exon 3 were used to amplify a $0.5-\mathrm{kb}$ fragment of the wild-type Sat 1 allele (Supplemental Table 1 and Figure 1A). Cycle parameters were as follows: $95^{\circ} \mathrm{C}$ for 10 seconds followed by 35 cycles of $95^{\circ} \mathrm{C}$ for 10 seconds, $58^{\circ} \mathrm{C}$ for 30 seconds, and $68^{\circ} \mathrm{C}$ for 3 minutes.

\section{Figure 5}

Increased hepatotoxicity in Sat1 ${ }^{-1-}$ mice. (A and B) Serum ALT and liver GSH levels in Sat1+/+ (white bars) and Sat1-/- (black bars) mice 0,2 , and 12 hours after administration of $250 \mathrm{mg} / \mathrm{kg}$ APAP. Results are mean \pm SEM ( $n=4-8$ per group). ${ }^{*} P<0.05$ versus time 0 Sat $1^{+/+}$; ${ }^{\#} P<0.05$ versus time 0 Sat1 $^{-1-}$. (C and D) Representative H\&E-stained

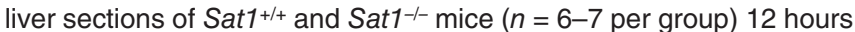
after administration of $250 \mathrm{mg} / \mathrm{kg}$ APAP, showing liver necrosis in Sat1 ${ }^{-/-}$mice. Scale bars: $100 \mu \mathrm{m}$.
Analysis of RNA. Total RNA (10 $\mu \mathrm{g})$ was separated on a $1.2 \%$ agarose formaldehyde gel in MOPS buffer and transferred to Hybond-XL nylon membranes (Amersham). The blots were probed with a 1.4-kb Sat1 cDNA and a 0.6-kb mouse GAPDH cDNA probe. For RT-PCR, total RNA $(2 \mu \mathrm{g})$ was reverse transcribed using random hexamers and Moloney Murine Leukemia Virus reverse transcriptase (Progen), as recommended by the manufacturer. Primer P8 in exon 2 and antisense primer P9 in exon 4 (Figure 2A and Supplemental Table 1) were used to amplify Sat $1 \mathrm{cDNA}$ fragments. GAPDH cDNAs were RT-PCR amplified using established primer sequences (17).
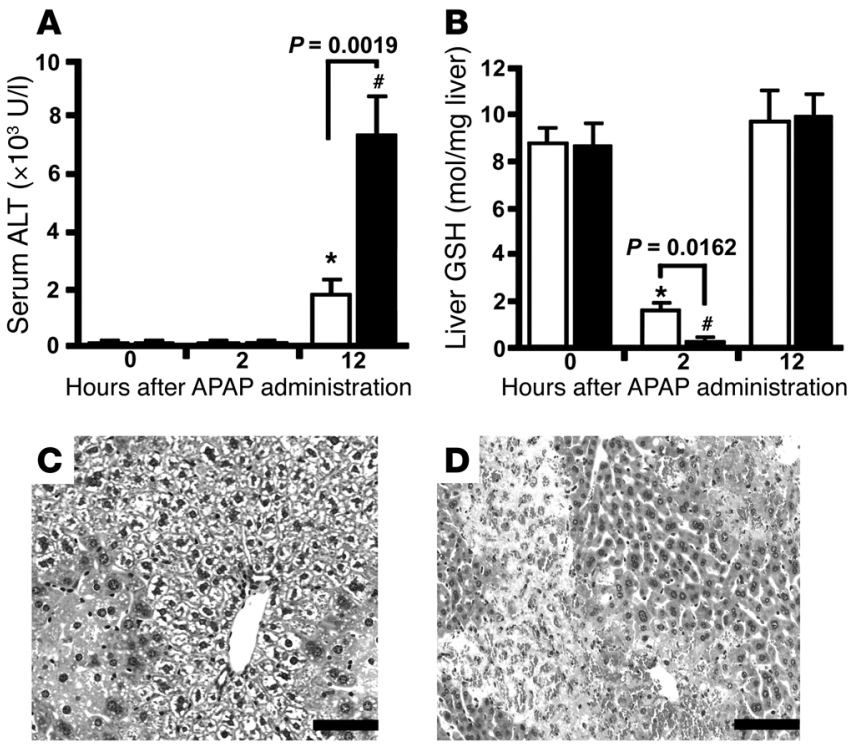

Sat $1^{+/+}$

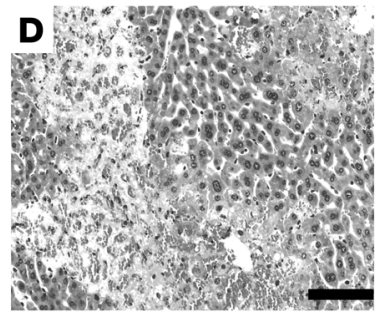

Sat1 ${ }^{--}$ 
Table 2

Blood, urinary, and cecal profiles of Sat1+/+ and Sat1-/- mice

\begin{tabular}{|c|c|c|}
\hline & $\operatorname{Sat1}^{+/+}(n)$ & Sat1-/- $(n)$ \\
\hline \multicolumn{3}{|l|}{ Plasma } \\
\hline Oxalate, $\mu \mathrm{M}$ & $8.1 \pm 0.8(12)$ & $13.0 \pm 1.0(10)^{\mathrm{C}}$ \\
\hline \multicolumn{3}{|l|}{ Serum } \\
\hline $\begin{array}{l}\mathrm{SO}_{4}{ }^{2-}, \mathrm{mM} \\
\mathrm{Cl}^{-}, \mathrm{mM} \\
\mathrm{PO}_{4}{ }^{2-}, \mathrm{mM} \\
\mathrm{Na}^{+}, \mathrm{mM} \\
\mathrm{K}^{+}, \mathrm{mM} \\
\mathrm{Ca}^{2+}, \mathrm{mM} \\
\text { Creatinine, } \mu \mathrm{M}\end{array}$ & $\begin{aligned} 0.64 & \pm 0.02(10) \\
114.1 & \pm 1.1(8) \\
2.54 & \pm 0.14(8) \\
145.0 & \pm 1.9(5) \\
6.1 & \pm 0.9(5) \\
2.34 & \pm 0.02(8) \\
16.7 & \pm 1.1(7)\end{aligned}$ & $\begin{aligned} 0.27 & \pm 0.03(8)^{\mathrm{D}} \\
115.9 & \pm 1.5(8) \\
2.73 & \pm 0.15(8) \\
144.8 & \pm 0.5(5) \\
6.3 & \pm 0.7(5) \\
2.34 & \pm 0.01(8) \\
15.5 & \pm 0.7(7)\end{aligned}$ \\
\hline \multicolumn{3}{|l|}{ Whole blood } \\
\hline $\mathrm{pH}$ & $7.34 \pm 0.02(8)$ & $7.35 \pm 0.02(8)$ \\
\hline \multicolumn{3}{|l|}{ Urine } \\
\hline $\begin{array}{l}\text { Oxalate/creatinine } \\
\mathrm{SO}_{4}{ }^{2-} / \text { creatinine }^{\mathrm{A}} \\
\mathrm{Ca}^{2+} / \mathrm{creatinine}^{\mathrm{A}} \\
\mathrm{Glycolate} / \mathrm{creatinine}^{\mathrm{A}} \\
\mathrm{Cl}^{-} / \mathrm{creatinine}^{\mathrm{A}} \\
\mathrm{PO}_{4}{ }^{2-} / \mathrm{creatinine}^{\mathrm{A}} \\
\mathrm{Total}_{\text {protein, } \mathrm{ng} / \mu \mathrm{l}} \\
\text { Creatinine, } \mathrm{mM} \\
\mathrm{pH}\end{array}$ & $\begin{aligned} 0.33 & \pm 0.05(11) \\
10.44 & \pm 0.56(5) \\
0.27 & \pm 0.09(7) \\
0.18 & \pm 0.02(9) \\
25.28 & \pm 11.26(3) \\
10.32 & \pm 2.73(7) \\
2.07 & \pm 0.81(10) \\
3.28 & \pm 0.27(11) \\
7.24 & \pm 0.17(8)\end{aligned}$ & $\begin{aligned} 0.69 & \pm 0.08(8)^{\mathrm{E}} \\
12.07 & \pm 0.30(6)^{\mathrm{E}} \\
0.20 & \pm 0.08(7) \\
0.18 & \pm 0.03(9) \\
28.75 & \pm 5.76(5) \\
10.29 & \pm 2.58(7) \\
1.37 & \pm 0.77(10) \\
3.73 & \pm 0.31(8) \\
6.99 & \pm 0.28(8)\end{aligned}$ \\
\hline \multicolumn{3}{|l|}{ FEIB } \\
\hline $\begin{array}{l}\mathrm{SO}_{4}{ }^{2-} \\
\mathrm{Ca}^{2+} \\
\mathrm{PO}_{4}{ }^{2-}\end{array}$ & $\begin{array}{c}0.38 \pm 0.03(5) \\
0.021 \pm 0.007(7) \\
0.079 \pm 0.024(7)\end{array}$ & $\begin{array}{r}0.96 \pm 0.12(6)^{\mathrm{D}} \\
0.020 \pm 0.008(7) \\
0.080 \pm 0.023(7)\end{array}$ \\
\hline \multicolumn{3}{|l|}{ Cecal } \\
\hline $\begin{array}{l}\text { Oxalate, } \mu \mathrm{mol} / \mathrm{g} \\
\mathrm{SO}_{4}^{2-}, \mu \mathrm{mol} / \mathrm{g} \\
\mathrm{H}_{2} \mathrm{O}, \%\end{array}$ & $\begin{array}{l}18.6 \pm 2.2(11) \\
10.7 \pm 1.2(11) \\
66.8 \pm 2.5(13)\end{array}$ & $\begin{array}{l}12.7 \pm 1.1(11)^{\mathrm{E}} \\
15.1 \pm 1.2(11)^{\mathrm{E}} \\
67.9 \pm 1.5(14)\end{array}$ \\
\hline
\end{tabular}

Results are mean \pm SEM. AMolar ratio. ${ }^{B}$ Ratio between [serum or plasma creatinine $\times$ (urine $\mathrm{SO}_{4}{ }^{2-}, \mathrm{PO}_{4}^{2-}$, or $\left.\mathrm{Ca}^{2+}\right)$ ] and [urine creatinine $\times$ (serum or plasma $\mathrm{SO}_{4}{ }^{2-}, \mathrm{PO}_{4}{ }^{2-}$, or $\mathrm{Ca}^{2+}$ )] ; all measurements in mM. ${ }^{C} P<0.001 ; D P<0.0001 ;{ }^{E} P<0.05$ versus $S a t 1^{+/+}$.

tography with suppressed conductivity detection using a Dionex ICS2000 running Chromeleon 6.80 $(32,33)$. Upon collection of $100 \mu \mathrm{l}$ serum and urine, $10 \mu \mathrm{HCl}(8 \mathrm{M})$ was quickly added, and the samples were frozen at $-80^{\circ} \mathrm{C}$ to prevent oxalate precipitation and oxalogenesis. Serum and urine creatinine levels were quantitated enzymatically using a Vitros 5.1 FS chemistry analyzer (Ortho-Clinical Diagnostics). Serum $\mathrm{PO}_{4}{ }^{2-}, \mathrm{Na}^{+}, \mathrm{K}^{+}, \mathrm{Cl}^{-}, \mathrm{Ca}^{2+}$, and ALT concentrations were assayed by a commercial pathology laboratory (Sullivan Nicolaides Pathology) using a Vitros 250 chemistry analyzer (Ortho-Clinical Diagnostics). Urinary glycolate levels were quantitated using an Agilent 6890 GC and 5973A MSD running MSD Chemstation B.01.00. Urine total protein levels were quantitated using a protein microassay kit (BioRad). Whole blood and urine $\mathrm{pH}$ was measured with an ISFET pH meter (Shindengen). Hepatic GSH levels were assayed using a commercially available kit (Cayman Chemical Co.). $\mathrm{H}_{2} \mathrm{O}$ content of cecal samples was determined by weighing samples before and after they were desiccated under vacuum for 30 hours at $25^{\circ} \mathrm{C}$. Kidney and liver IDUA activity was measured using a fluorometric assay (34).

Histopathological analysis. Tissues were dissected into approximately 50 volumes of $10 \%$ buffered formalin and fixed for 3 days prior to paraffin embedding. Embedded tissue was sectioned, stained with H\&E or by the Yasue histochemical method (35) for detecting calcium oxalate crystals, and examined by light microscopy. Liver sections were scored blinded to genotype for the severity of degeneration and necrosis using a $0-5$ scale as previously described (36).

APAP administration. APAP (Sigma-Aldrich) was dissolved in saline and filter-sterilized. At approximately 3 months of age, mice received i.p. injection of a $250-\mathrm{mg} / \mathrm{kg}$ dose of APAP ( $n=4-8$ per group). Mice were sacrificed at 2 or 12 hours after APAP administration.

Statistics. Statistical significance between $\mathrm{Sat}^{+/+}$and Sat $1^{-/-}$or Sat $1^{+/-}$groups was assessed using an unpaired

Membrane vesicle preparation, transport studies, and Western blotting. BLMVs and BBMVs were isolated from mouse kidney, liver, and intestine using previously described methods $(29,30)$. Vesicles were preincubated in buffer containing $120 \mathrm{mM}$ potassium gluconate, $30 \mathrm{mM} \mathrm{KCl}$, and $15 \mathrm{mM}$ HEPES pH 8.2 for 2 hours at $20^{\circ} \mathrm{C}$. The uptakes of $\mathrm{SO}_{4}{ }^{2-}(0.1 \mathrm{mM})$ and oxalate $(20 \mu \mathrm{M})$, each performed in quadruplicate, were measured at 10 seconds $\left(\mathrm{SO}_{4}{ }^{2-}\right)$ and 30 seconds (oxalate) in media containing $150 \mathrm{mM}$ potassium gluconate and $15 \mathrm{mM}$ HEPES, $\mathrm{pH}$ 8.2, by the rapid filtration technique $(23,31)$. BLMV protein $(5 \mu \mathrm{g})$ was separated on a $10 \%$ SDS polyacrylamide gel and transferred to nylon membrane (Immobilon-FL membrane; Millipore). Sat1 proteins were detected with a Sat1 antibody (5) provided by L.P. Karniski (University of Iowa, Iowa City), with IRDye CW800-labeled anti-mouse IgG (diluted 1:20,000) and the Odyssey Imaging System (LI-COR Biotechnology). All experiments were repeated at least twice.

Biochemical analyses. Mouse blood was collected from the submandibular vein using an animal bleeding lancet (MEDIpoint Inc.). Single urine samples were collected upon spontaneous micturition during mouse handling, prior to blood collection. A turbidimetric assay was used to measure free sulfate levels (17). Oxalate was measured by ion chroma-
Student's 2-tailed $t$ test. Statistical significance between Sat $1^{+/+}$and Sat $1^{-/-}$ groups with respective controls at time point 0 was evaluated using 1-way ANOVA followed by Duncan's multiple range test. Differences in histology scores were analyzed by the Mann-Whitney test. In all cases, a $P$ value less than 0.05 was considered significant.

\section{Acknowledgments}

We thank S. Gibson, K. Colobong, P. Addison, I. Wilkie, and I. Shiels for scientific assistance. L.A. Clarke holds an investigatorship award through the Child and Family Research Institute. This work was supported in part by the Australian Research Council and the National Health and Medical Research Council.

Received for publication August 18, 2009, and accepted in revised form January 6, 2010.

Address correspondence to: Daniel Markovich, School of Biomedical Sciences, University of Queensland, St. Lucia, Queensland 4072, Australia. Phone: 61.7.3365.1400; Fax: 61.7.3365.1766; E-mail: d.markovich@uq.edu.au. 
1. Greger R, Lang F, Oberleithner H, Deetjen P. Handling of oxalate by the rat kidney. Pflugers Arch. 1978;374(3):243-248.

2. Markovich D. Physiological roles and regulation of mammalian sulfate transporters. Physiol Rev. 2001;81(4):1499-1533.

3. Falany CN. Enzymology of human cytosolic sulfotransferases. FASEB J. 1997;11(4):206-216.

4. Bissig M, Hagenbuch B, Stieger B, Koller T, Meier PJ. Functional expression cloning of the canalicular sulfate transport system of rat hepatocytes. J Biol Chem. 1994;269(4):3017-3021.

5. Karniski LP, Lotscher M, Fucentese M, Hilfiker H, Biber J, Murer H. Immunolocalization of sat-1 sulfate/oxalate/bicarbonate anion exchanger in the rat kidney. Am J Physiol. 1998;275(1 Pt 2):F79-F87.

6. Quondamatteo F, et al. Localization of the sulfate/ anion exchanger in the rat liver. Am J Physiol Gastrointest Liver Physiol. 2006;290(5):G1075-G1081.

7. Lee A, Beck L, Markovich D. The mouse sulfate anion transporter gene Sat1 (Slc26a1): cloning, tissue distribution, gene structure, functional characterization, and transcriptional regulation thyroid hormone. DNA Cell Biol. 2003;22(1):19-31.

8. Markovich D, Aronson PS. Specificity and regulation of renal sulfate transporters. Annu Rev Physiol. 2007;69:361-375

9. Regeer RR, Lee A, Markovich D. Characterization of the human sulfate anion transporter (hsat-1) protein and gene (SAT1; SLC26A1). DNA Cell Biol. 2003;22(2):107-117.

10. Clarke LA, et al. Murine alpha-L-iduronidase: cDNA isolation and expression. Genomics. 1994;24(2):311-316

11. Neufeld EF, Muenzer J. The mucopolysaccharidoses. In: Scriver CR, Beaudet AL, Sly WS, and Valle D, eds. The Metabolic Basis of In herited Disease. New York, NY: McGraw-Hill; 1994:2465-2498.

12. Lee A, Dawson PA, Markovich D. NaSi-1 and Sat-1: Structure, function and transcriptional regulation of two genes encoding renal proximal tubular sulfate transporters. Int J Biochem Cell Biol. 2005;37(7):1350-1356.

13. Mount DB, Romero MF. The SLC26 gene family of multifunctional anion exchangers. Pflugers Arch.
2004;447(5):710-721.

14. Clarke LA, et al. Murine mucopolysaccharidosis type I: targeted disruption of the murine alpha-L-iduronidase gene. Hum Mol Genet. 1997;6(4):503-511.

15. Morris ME, Levy G. Serum concentration and renal excretion by normal adults of inorganic sulfate after acetaminophen, ascorbic acid, or sodium sulfate. Clin Pharmacol Ther. 1983;33(4):529-536

16. Kim H, Rozman P, Madhu C, Klaassen C. Homeostasis of sulfate and $3^{\prime}$-phosphoadenosine $5^{\prime}$-phosphosulfate in rats after acetaminophen administration. J Pharmacol Exp Ther. 1992;261(3):1015-1021.

17. Lee S, Dawson PA, Hewavitharana AK, Shaw PN, Markovich D. Disruption of NaS1 sulfate transport function in mice leads to enhanced acetaminophen-induced hepatotoxicity. Hepatology. 2006;43(6):1241-1247.

18. Veeramachaneni V, Makalowski W, Galdzicki M, Sood R, Makalowska I. Mammalian overlapping genes: the comparative perspective. Genome Res. 2004;14(2):280-286.

19. Asplin JR. Hyperoxaluric calcium nephrolithiasis. Endocrinol Metab Clin North Am. 2002;31(4):927-949.

20. Schreiner GF, Harris KP, Purkerson ML, Klahr S. Immunological aspects of acute ureteral obstruction: immune cell infiltrate in the kidney. Kidney Int. 1988;34(4):487-493.

21. Dawson PA, Beck L, Markovich D. Hyposulfatemia, growth retardation, reduced fertility and seizures in mice lacking a functional $\mathrm{NaS}_{\mathrm{i}}-1$ gene. Proc Natl Acad Sci U S A. 2003;100(23):13704-13709.

22. Wang $Z$, et al. Renal and intestinal transport defects in Slc26a6-null mice. Am J Physiol Cell Physiol. 2005;288:C957-C965.

23. Jiang $Z$, et al. Calcium oxalate urolithiasis in mice lacking anion transporter Slc26a6. Nat Genet. 2006;38(4):474-478.

24. Gill RQ, Sterling RK. Acute liver failure. J Clin Gastroenterol. 2001;33(3):191-198.

25. Mitchell J, Jollow D, Potter W, Davis D, Gillette J, Brodie B. Acetaminophen-induced hepatic necrosis. I. Role of drug metabolism. J Pharmacol Exp Ther. 1973;187(1):185-194.

26. DeLeve LD, Kaplowitz N. Glutathione metabo- lism and its role in hepatotoxicity. Pharmacol Ther. 1991;52(3):287-305.

27. Henderson CJ, Wolf CR, Kitteringham N, Powell H, Otto D, Park BK. Increased resistance to acetaminophen hepatotoxicity in mice lacking glutathione S-transferase Pi. Proc Natl Acad SciU S A. 2000;97(23):12741-12745.

28. Dawson P, Markovich D. Genetic polymorphisms of human sulfate transporters. Curr Pharmacogenomics. 2007;5:262-274.

29. Hilden SA, Johns CA, Guggino WB, Madias NE. Techniques for isolation of brush-border and basolateral membrane vesicles from dog kidney cortex. Biochim Biophys Acta. 1989;983(1):77-81.

30. Meier PJ, Sztul ES, Reuben A, Boyer JL. Structural and functional polarity of canalicular and basolateral plasma membrane vesicles isolated in high yield from rat liver. J Cell Biol. 1984;98(3):991-1000.

31. Tenenhouse HS, Scriver CR. The defect in transcellular transport of phosphate in the nephron is located in brush-border membranes in X-linked hypophosphatemia (Hyp mouse model). Can J Biochem. 1978;56(6):640-646.

32. McWhinney BC, Cowley DM, Chalmers AH. Simplified column liquid chromatographic method for measuring urinary oxalate. J Chromatogr. 1986;383(1):137-141.

33. Palgi N, Vatnick I, Pinshow B. Oxalate, calcium and ash intake and excretion balances in fat sand rats (Psammomys obesus) feeding on two different diets. Comp Biochem Physiol A Mol Integr Physiol. 2005;141(1):48-53.

34. Hopwood JJ, Muller V, Smithson A, Baggett N. A fluorometric assay using 4-methylumbelliferyl alpha-L-iduronide for the estimation of alpha-L-iduronidase activity and the detection of Hurler and Scheie syndromes. Clin Chim Acta. 1979;92(2):257-265.

35. Yasue T. Histochemical identification of calcium oxalate. Acta Histochem Cytochem. 1969;2:83-95.

36. Manautou JE, Silva VM, Hennig GE, Whiteley HE. Repeated dosing with the peroxisome proliferator clofibrate decreases the toxicity of model hepatotoxic agents in male mice. Toxicology. 1998;127(1-3):1-10 